\title{
Analysis on Symbolic Meaning of Blanche
}

\author{
Jinchao $\mathrm{Xu}^{1}$ \\ ${ }^{1}$ School of Foreign Language, Linyi University, China \\ Correspondence: Jinchao $\mathrm{Xu}$, School of Foreign Language, Linyi University, linyi city, China Tel: \\ 86-138-6996-0078. E-mail: yiming19770109@126.com
}

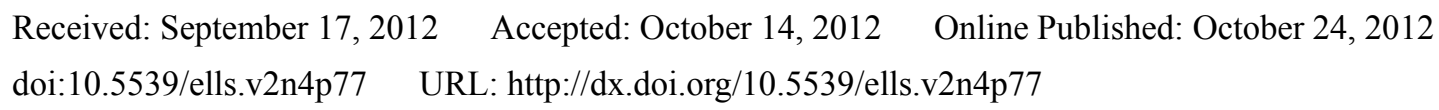

\begin{abstract}
The paper aims to analyze the symbolic meaning of Blanche in Tennessee Williams' A Streetcar Named Desire.

William has consistently employed symbolism to universalize the significance of the realistic action he posits, not only because he thinks of symbolism as essential of art, but because it seems to be characteristic of his personal reactions to life in general. Blanche DuBois, the very name, her appearance and dressing, her illusionary vision of the world, and her lantern together with her desire all contribute to William's symbolic portrait of a southern belle. Displaced in an unfavorable environment, Blanche finally collapses mentally and excluded out of the new industrial world.
\end{abstract}

Keyword: symbolism, desire, Blanche, illusion, lantern

\section{Introduction}

Of all Williams's plays, A Streetcar Named Desire is the most controversial one. That is why it is the focus of so many critics from different schools. Some critics comment on the confrontation between Stanley and Blanche from the gender perspective. It is argued that the characters' difference in sexuality can be traced to their different gender consciousness. Some others explore the play from a cultural respect to find out the forces that destroyed the southern culture. Still another group is psychologically oriented and views Stanley and Blanche as unique individuals and the Streetcar as Williams's display of unconscious warfare between two opposing forces. While Harold Bloom in his introduction of Modern Critical Interpretation of A Streetcar stresses the fall of Blanche is a parable of the failure of American literary imagination to rise above its recent myths of recurrent defeat and he regards Blanch as a failed Whitmanian, and eccentrically a failed aesthetic identity.

But my brief study assures me that $A$ Streetcar Named Desire is a dramatic masterpiece which applies symbolism to carrying out the conflicts and dramatizing major themes of the play. "Art is made out of symbols the way your body is made out of vital tissue." Tennessee Williams once said. William has consistently employed symbolism to universalize the significance of the realistic action he posits, not only apparently, because he thinks of symbolism as essential of art, but also because it seems to be characteristic of his personal reactions to life in general. William once said that whenever he stayed in New Orlands, he lived "near the main street of the Quarter which is named Royal. Down this street, running on the same tracks, are two street cars, one named DESIRE and the other CEMETERY. Their indiscourageable progress up and down Royal struck me as having some symbolic bearing of a broad nature on the life in the Vieux Carre-and everywhere else for that matter."

All the images, symbols and allusions, even what appear to be only the most casual or realistic details in Streetcar, combine to reveal a tragic parable of the pitiable and terrible fate of the human soul. We can find ample illustrations of symbolism in A Streetcar Named Desire: it might be an incident that takes on meaning, such as the card games, the rape and Blanche's repeated bath; it might be a person representing a culture, take Blanche as an example; it might be a conventional object or device - the naked bulb, paper lantern, and the color - that becomes symbolic of meanings within and without the play. The most important, the main characters in the play are distinctive symbols themselves. Here I will focus on Blanche and detail her symbolic meanings.

In its broad sense, symbolism refers to the naming of something (known as vehicle) that represents something else (known as tenor) by association, resemblance, or convention, especially a material object used to represent something invisible. Just as characterization, dialogue and plot work on the surface to move the story along, symbolism works under the surface to tie the story's external action to the theme. In literature, "symbolism" may refer to the use of abstract concepts, as a way to obfuscate any literal interpretation, or to allow for the broader 
applicability of the prose to meanings beyond what may be literally described. Many writers - in fact, most or all authors of fiction - make the symbolic use of concepts and objects as rhetorical devices central to the meaning of their works.

\section{Discussion}

Among symbols in A Streetcar Named Desire, Blanche is the most meaningful one. The very name of Blanche DuBois is symbolic and suggests her conflicted character. "Blanche" means white, the color signifying essential purity and even innocence but easily stained. In the play, when she tells Mitch the meaning of her name, she puts it as "white woods. Like an orchard in spring." (138) But contrary to her translation, we can get the impression that Blanche is past her spring, and past the essential purity. Even innocence of Blanche, the white, is easily stained, being covered by the Dubois woods. Rudy Cohn, has seen the name as a fantasy, suggesting that "Anglicized, Blanche's name is Blanche, and under her chaste surface, Blanche lusts for boys." The purity is the old south tradition and education she wants to adhere to, but it is past its spring and is undermined by the unavoidable social forces. She and her family owned a large plantation Belle Reve and just like the name suggests she lived in the dream. She was cultivated a romantic and unrealistic character and refined taste in such a surrounding and environment. Consequently she was much vulnerable of her family's downfall and the rigid reality. Her age-about thirty- also suggests that she passes her best time and steps into a kind of withering and decay. The loss of the plantation is mainly the result of the social development despite the fact that "piece by piece, our improvident grandfathers and father and uncles and brothers exchanged the land for their epic fornications - to put it plainly." Overall, Blanche's entire name is symbolic because it reflects her true nature and the social changes in a very clear way.

Besides her name, her clothing and manner are also symbolic. Blanche suggests the image of a delicate but fragile "moth" when she first appears in the play. William writes in the stage directions:

Her appearance is incongruous in this setting. She is daintily dressed in a white suit with a fluffy bodice, necklace and earrings of pearl, white gloves and hat, looking as if she were arriving at a summer tea or cocktail party in the garden district. Her delicate beauty must avoid a strong light. There is something about her uncertain manner, as well as her white clothes, that suggests a moth. (scene 1)

Blanche's very appearance does not harmonize with the atmosphere of the French Quarter of New Orleans. Such a setting suggests a harsh and sorrowful environment, especially when we know that it is a place where the Negro homesick "blues" originated. "The blues is an expression of the loneliness and rejection, the exclusion and isolation of the Negro and their longing for love and connection. Blanche, too, is looking for a home, abandoned and friendless." The city is full of sharp contrasts: old French architecture and new rhymes of jazz, a kind of old world refinement mixed with the grit of poverty and modern life, decay and corruption alongside a regenerative power of desire and procreation. In the American's imagination the city is also associated with the desire and the most direct kind of sexuality for there "make marry" is tradition and prostitute is licensed. The setting prepares a general aura of conflicts and tensions for the play. And the main character is beset with contradictions. Even from the beginning we can get the impression that her clothing is of too much refined style with necklace, pearl earring, gloves and hat. She is absolutely beautiful, but her beauty must be very carefully protected, for it is so delicate that even "a strong light" is able to destroy it. The way she dresses herself is that for a "summer tea or cocktail party", but she will very soon find that there is no such graceful things here but the vulgar poker games. She will come to know as well that not only her appearance but her manners, her likes and dislikes, and virtually her outlook on life and the world proves to be unsuitable in the new world, therefore it is only too natural that she feels "uncertain".

Soon we learn that she was brought up in her plantation home - Belle Reve which symbolizes the decayed Old South. Belle Reve, Blanche's ancestral plantation home, is a great big place with "white columns" which is as superb as she appears to be. As the name which is of French origin suggests, it means "beautiful dream", something beautiful, once existed, but now faded away. Therefore, the name also has symbolic meanings. The glories of Belle Reve have been founded on its forebears. For people living in it, it stands for a genteel society and the charm and dignity of life. But when it collapses, the ravages of decay have eaten away the human body and soul as they have destroyed the physical structures of the plantation itself. The figure of the magnificent survivor, maintaining the stance of goodness against overwhelming destructiveness, is hopelessly flawed, ill-equipped to represent the attractions of what she attempts to keep and show. Blanche had stayed on at Belle Reve before she came to her sister. She had watched the tubercular deaths of her mother and other sister, and stood helplessly by while the estate was drained. Blanche remains prisoner of the traditional notions about women of the old cavalier South, where economic dependency was the order of the day, and where women were 
taught attractiveness, virtue, and gentility led automatically to happiness. Hence women like Blanche were ill-equipped to survive in a changing world by any means except physical attractiveness. Blanche attempts to use her fading good-look to win the hand of a charming suitor, but she is ironically restricted by her affected charm and manners. What's worse, she had married a delicate poetic youth, only to discover that he was a homosexual. The miseries of that marriage are climaxed by his suicide, which echoes in her mind so often that she cannot get out of the memory of her relationship with the young boy.

Together with the impression of Moth-that is longing for the light in the lantern, unavoidably crash onto the lantern or be singed by the flame, the drama pictures the last of the southern ladies who is so sensitive, fragile and in blind hope that she is ultimately self-destructive. Blanche's tragic fate is apparent from the very beginning of the play - a Southern belle who clings to her illusion is destined to be pressed by harsh reality.

Throughout the play Blanche is portrayed as a romantic idealist undone by a graceless and callous age. Her refusal to face the reality pervades the whole play. From the very beginning to the end of the play, Blanche always avoids appearing in direct, bright light, especially in front of her suitor, Mitch. It is clear that she avoids light in order to prevent others from seeing the reality of her fading beauty. Blanche covers the exposed light bulb in the Kowalski apartment with a Chinese paper lantern, and she even refuses to go on dates with Mitch during the day time or to well-lit locations. When Mitch forces her to stand under the light, telling that he doesn't mind her age but her deceitfulness, Blanche responds by her preferring magic rather than reality. Blanche's inability to tolerate light means her escaping the reality away.

In fact it is also her outlook of life and the world. She prefers dream instead of the reality because she was caged in the good old days. She took the delicate clothes and ornaments with her, hoping for "summer tea or cocktail party", even though she was almost penniless. But the old day and world leaves her no more than an empty soul and a hypocritical manner to hold up her identity. Her conflicts with Stanley are the conflicts of the south and the north, or two civilizations - a delicate but withering one and a primitive but promising one. It is also a conflict of Blanche herself. She never expected she would sink to such a disgusted and miserable condition. She denied to descend in the animal world because she thought "maybe we are a long way from being made in God's image...but such kind of new light have come into the world since then". What's more she is so blind to the reality that she insists "that we have got to make grow! And cling to, and hold as our flag!". "Blanche, as the last vestige of a dying aristocratic culture, is the heroine on a social level. She represents all that is sacred within this culture - the love for language, the appreciation of art and music, the "beauty of the mind and richness of the spirit and tenderness of the heart." She clung to the old world and its outlook, naively believing in her ideal understanding of the world although she had experiences of innumerable frustration and failure.

The Chinese lantern symbolizes the illusion world Blanche is ready to retreat into any time feeling unsafe. Blanche has to disguise a failed life by decorating the shabby room, adorning the light bulb to escape the unpleasant reality reflected in mirrors. She even tries to light a candle, and "pretending that we are sitting in a little artists' café on the Left Bank in Paris!" when she stays together with Mitch. "Her poise is an illusion she presents to shield others (but most of all, herself) from her reality, and an attempt to make herself still attractive to new male suitors." All these suggest that she makes every effort to create around her a dreamlike world, an old and familiar world of Belle Reve. Her love, her purpose of life, her dignity, her charm as a belle only exist in the genteel world of Belle Reve. When the plantation collapsed, she wants to stay in the illusion where she has a dignity. She tries to forge a new home in social worlds that is contrary to her and do not welcome her. Yet her tactics are worn out. Her efforts never work in the reality, in a world inhabited and dominated by the animal like Stanley and his party. Being forced to face the kind of reality that she refuses to recognize as significant is the cause of Blanche's breakdown. In the last scene, as Blanche is led away, Stanley tears the paper lantern off the light bulb and extends it to her: "she cries out as if the lantern was herself". Blanche is as delicate and pathetic as a paper lantern; she cannot face up to the hard light of Stanley's vision of reality.

The New Orleans street figures are analogues of all that reality means to Blanche: violence, theft, immorality and bestiality. No wonder she tries to escape it. In scene 6, she returns to the telephone: "Western Union? Yes! I want to - Take down the message! In desperate, desperate circumstance! Help me! Caught in a trap. Caught in Oh!" but There is no escaping reality. When Blanche is escorted out by the kindness of strangers to the asylum, she has retreated into a deeper state of delusion, that is, the vulnerable southern aristocrat again.

Let us come to Blanche's desire. The desire Blanche represents is and always will be enigmatic and ambiguous wonderfully refreshing but despondently dangerous. The title itself reveals one of the most important symbols, that is, the streetcar named Desire is the most important symbol for Blanche and her tragic fate.

Blanche's first line in New Orleans, a reference to the streetcars that brought her here, suggests a movement 
beyond physical needs to ineffable matters of the spirit: "They told me to take a streetcar named Desire, and then transfer to one called Cemeteries and ride six blocks and get off - Elysian Field". It plants the notion of movement from one place to another, which might be summed up with Blanche spiritual journey from desire to madness. We will see her progress from the "desire" that causes her to lose her job as a schoolteacher, to a desire for "rest" to the burial of crossing over to a "paradise" beyond personal responsibility.

In a sense we can say Blanche bears the desire of sexuality from her family. Just like Raymond William put it: "we are the creature of our past. From the moment of our birth, we are inevitably haunted by every inherited debt." (Drama from Ibsen to Brecht) When once explains the loss of plantation Belle Reve, she confesses that it is due to "the improvident grandfathers and father and uncles and brothers exchanged the land for their epic fornication". Her sister Stella also once says that "when he is away for a week I nearly go wild". Stella tolerates her husband's primal behavior because this is part of what attracted her in the first place. And their love and relationship are heavily based on powerful — even animalistic — sexual chemistry. The clan has such a desire and Blanche no doubt inherits such a kind of disposition. But besides the instinct impulse for the sexuality, her desire is a complex of escaping, forgetting, love, company, and rest. She once loves a boy deeply when she is only sixteen and her careless action partly leads to the boy's death. She tries but fails to forget it and escape the sense of guilty. The death of the relatives adds more loneliness and she has to seek company and love from strangers. When driven out of her former city, she meets Mitch, the last salvation. While her desire for a rest is ruined by her notorious past. Her desire always confronts death - first love's death, relatives' death, and her own mental death when taken to the asylum in the end.

Blanche failed her young husband in his time of need, so she bears or shares a sense of responsibility and experiences guilt over the loss. As she reveals to Mitch in Scene 6, when she was sixteen she fell "all at once and much, much too completely" in love with a young boy Allan - a love that blindingly lit up what before had existed "half in shadow"(150). She was attracted to him because he was "different", with "a softness and tenderness". But she failed her young husband for she "unable to stop" and she suddenly loose her tongue that she "saw and knew" and it disgusted her. In a sense she indirectly talked him into killing himself. She witnessed the pathetic scene of the boy's death. Recognizing her complicity in Allan's death, her life since then has been a trail of attempted forgetfulness and of guilt.

Though deeply hurt by his desertion, Blanche still values the yellowing love letters, considering her former husband and their love the embodiment of youth, love and purity. Associating him with that time in her life in Belle Reve, the memory becomes her shackle to a new life. For one hand, she tries to forget the miserable experience. But her desire for love and her guilty feeling never escape her. Maybe frequently taking hot bathing is a good way to wash off her sense of sin and give her a fresh life. "Blanche's obsessive bathing is a nominal gesture of guilt and wished-for redemption." But consequent falling back on the wine suggests her failure of control herself. In fact, both her drinking and her bathing is an escape mechanism. There is no wonder that she is so weak and vulnerable. Spending carefree and luxury life for the childhood and youth, then witnessing the family's downfall, first love's death partly of her responsibility, and the death of the dearest relative one after another, how can a girl like Blanch face the world bravely?

Drowned in loneliness, helplessness and insecurity she is so thirsty for love and care that she dreams to get it by having "many intimacies with strangers" to "fill empty heart". Her desire for love and security are misunderstood as instinct desire for sex. Such a misunderstanding gradually misleads her own interpretation of her desire. Thus her subsequent "intimacy with strangers" fatefully takes her to the final downfall. Although Blanche tries to maintain a proper balance, being "gay" enough to entertain and entice the gentleman caller without being so sexually forward as to turn him away, she is regarded as "downright loco-nuts". Her romantic dreams and aspirations are each time deflated and destroyed. She even mixes up with a seventeen-year-old student. She wants to get the same or familiar sense of love-a very delicate and different softness and tenderness from her first love- from a boy with similar age. We do not know whether she gets it or not. But the outcome of her getting mixed-up-with the student is her expulsion from her teaching job, and after that, she became a nymphomaniac and a town "character".

After all the men are tired of her, she is eventually driven out of the town, a complete social outcast now. In frightened flight from the mounting horrors of her existence, she seeks a haven with her sister, Stella. But she does not learn much from her past and continues her romantic interpretation. Her romantic attempt to achieve a union with Mitch ends her hope. In fact Mitch is very likely to be the salvation of Blanch although their differences are so obvious. There is a similarity that transcends the age and race. That is they are both lonely and seek eagerly for companionship. Mitch's girlfriend is dead and his mother is dying. He is very lonely. Blanch also feels her loneliness deeply. And the possible death of Mitch's mother recalls her loneliness when her first 
love died. She opens her heart to Mitch and tells him frankly her first love and her guilt about the boy's death. The death-related situation gives birth to the same desire for the company. Mitch confesses that "you need somebody. And I need somebody too. Could it be-you and me?" and he kisses Blanch in her lips. At that time Blanche claims that "sometimes - there is God-so quickly" and it means she receives him. But the romance lasts so short and the hope leaves too abruptly. Although partly for the primitive Stanley, her own insincerity and her unrealistic attitude contribute a lot to the failure. She hides her notorious past. It is forgivable because her past is really destructive and fatal. But she does not stop her hypocritical and pretension. When Mitch asks for reality, she, on the contrary, only "wants magic". She does not tell the truth but tell what ought to be the truth. Even before the last salvation she refuges any realism.

She goes on her fancy of love and her encounter with the "young man" - the fairy-taled "young prince out of the Arabian Nights" ends her imagination. And she eventually latches on to the romantically idealized Shep Huntleigh, a man who is attainable only in the realm of fantasy, a man who will value "a cultivated woman, a woman of intelligence and breeding" and whose beauty of "the mind and richness of the spirit and tenderness of the heart"(161) were not taken away. Such an image of a woman is Blanche's idealized herself in a refined world, much different from others' impression in the cruel reality, and an obvious demonstration of Blanche's illusionary nature.

However, as if thinking it is still not tragic enough, the playwright arranges her relation with the animalistic Stanley, which puts an end not only to her love affairs but to her sane self. Such a romantic nature will never survive the cruel and animalized reality. Tragically and ironically, she is finally escorted to the mental institution by the Doctor. For Tennessee Williams, she is a symbol of the sensitive and the outcast, for her sensitivity invariably subjects her to mutilation. In each of her sexual involvement, she only reenacts the futility of the soul's romantic striving to escape, transcend, or imaginatively transform the "original sin" of its corrupt incarnation.

\section{Conclusion}

Thus Blanche, a south belle who clings to her delicate taste and refinement, experienced clan downfall, relatives' death and failure of romantic marriage, driven by poverty to seek shelter from sister, only found herself caged in the past, failing to seek desirable love and security, settled only in her own illusion and regarded insane from the around world.

As a south belle, Blanche is unable to hold on her plantation because of the social force, consequently fails to maintain what the genteel southern world stand for. But grown up in the old world, she is weak and vulnerable to face the reality and only seek comfort in her illusion. She is reluctant to accept her fading beauty as she is reluctant to accept the fact that she descends into poverty and a disgraceful world. When defeated by the death beloved relative and husband, she wants to seek company, ideal love and security through sexual activity in vain. Her identity is lost despite her every effort to forge the illusion and seek love and rest. Her whole life is a symbol of waning south aristocracy. Her insanity is the end of such a class's domination and the civilization it stands for. Her desire for ideal love and care does not succeed in the sexuality. At the same time her dreamlike understanding of the world, her self-delusions together with her split selfness never settles in the cruel reality. Thanks to William's excellent employment of symbolism, The Streetcar named Desire carries the desire of a south belle away in a pathetic way and provokes the vital criticism upon its very being.

\section{Reference}

Corrigan, Mary A. (1976). Modern Drama, 19(4).

Bloom, Harold. (1988). Modern Critical Interpretation of A Streetcar Named Desire. New York: Chelsea House Publisher.

Boxill, Roger. (1987). Modern Dramatists: Tennessee Williams. New York: St. Martin's Press.

Hurrell, John D. (1961). Two Modern American Tragedies: Reviews and Criticism of A Salesman and A Streetcar Named Desire. New York: Charles Scribner's Sons.

Jones, A. G. (1989). “Belles and Ladies” Encyclopedia of Southern Culture. Edited by Charles Reagan Wilson and William Ferris. Chapel Hill: University of North Carolina Press.

Kazan, Elia. (1963). "Notebook for A Street Car Named Desire” in Directors on Directing. Edited by Toby Cole and Helen Krich Chinoy. New York: Bobbs-Merrill.

Kazan, Elia, \& John Orr. (1985). Tragic Drama and Modern Society. London: Macmillan.

Kolin, Philip C. (1998). Tennessee Williams: A Guide to Research and Performance. London: Greenwood Press. 
Nelson, B. (1961). Tennessee Williams: His Life and Work. London: Peter Owen.

Pyron, Darden A. (1989). “Plantation Myth” Encyclopedia of Southern Culture. Edited by Charles Reagan Wilson and Williams Ferris. Chapel Hill: University of North Carolina Press.

Raymond, William. (1981). Drama from Ibsen to Brecht. London: Hogarth Press.

Roberts, Giselle. (2003).The Confederate Belle. Columbia: University of Missouri Press.

Roderick, J. M. (1986). From "Tarantula Arms" to "Della Robbia Blue" Modern Critical Interpretation a Streetcar Named Desire. Edited by Bloom Harold. NY: Chelsea House Publishers.

Showalter, Elaine. (1985). New Feminist Criticism: Essays on Women, Literature, and Theory. New York: Pantheon Books.

Williams, Tennessee. (1993). A Streetcar Named Desire. The Norton Anthology of American Literature. Edited by Nina Baym, et al. New York: W. W. Norton \& Company.

Williams, T. Harry. (1961). Romance and Realism in Southern Politics. Athens: University of Georgia Press.

\section{Author}

Jinchao, Xu: PHD student of The University of Suwon, lecturer of School of Foreign Language, Linyi University, 276000 China. E-mail: yiming19770109@126.com 